VASKA PEJIĆ, M.Sc. ${ }^{1}$

E-mail: vaska.pejic@um.si

TONE LERHER, Ph.D. ${ }^{1}$

E-mail: tone.lerher@um.si

BORUT JEREB, Ph.D. ${ }^{1}$

E-mail: borut.jereb@um.si

ANDREJ LISEC, Ph.D. ${ }^{1}$

(Corresponding author)

E-mail: andrej.lisec@um.si

${ }^{1}$ University of Maribor, Faculty of Logistics

Mariborska cesta 7, 3000 Celje, Slovenia
Transport Logistics

Preliminary Communication

Submitted: Feb. 29, 2016

Accepted: Sep. 21, 2016

\title{
LEAN AND GREEN PARADIGMS IN LOGISTICS: REVIEW OF PUBLISHED RESEARCH
}

\begin{abstract}
This paper provides a systematic review of published research on lean logistics, green logistics and the combination of both paradigms. Although prior research on all three topics exists, only a few have focused on the field of logistics as such. The present analysis comprises an examination of 98 scientific articles from 35 international journals, published between the years 1994 and 2015. The published studies are classified by next divisions: journal, paradigm, time distribution, research stream and sector-wise focus. Although key findings indicate that over the last couple of years research on all three topics has increased, a research gap regarding the studies of lean and green logistics when combined, has been identified. For all three topics the domination in research typology has been extracted. The findings indicate that most papers examined on the topic of lean logistics come from the manufacturing industries, whereas for the topic green logistics and a combination of green and lean topics no specific sector was identified.
\end{abstract}

\section{KEY WORDS}

logistics; lean; green; review of research;

\section{INTRODUCTION}

Contemporary technological developments, economic globalization and rapidly growing population are increasingly affecting the rising demand for products and services. The latter puts great pressure on logistics whose operations are often characterized by a high degree of manual control which consequently have a significant impact on the price of operations. It is therefore not surprising that there are many initiatives for possible improvements in the field of logistics. In other words, logistics plays a significant role in today's businesses, particularly on their effectiveness and competitiveness. For instance, a failure in material or information flow may result in costly time interruption. Hence, a well-functioning logistics system supporting all operational units is significant [1, $2]$. Here, it is noteworthy that global logistics cost was estimated at USD 9,177 billion in 2015 [3]. Therefore, any failure, inconsistency or any kind of waste may represent significant cost in the logistics system.

Besides eliminating wasteful or non-value added activities in logistics processes, one of the challenges is sustainable logistics for environmental protection. Especially in the developed economies, the environmental aspect and ecological consciousness on systems has increased drastically over the last two to three decades. This has been shown by BearingPoint research [4], where $35 \%$ of global companies state that they have incorporated a green supply chain policy in the company's vision. The environmental impact of logistics management within supply chain is vast due to occupying land for transportation and storage, transportation access, consuming fuel, transport and storage equipment, generating waste, producing loss and waste due to distribution processing, consuming material, etc. According to statistics of the "Internationale Energieagentur" almost one third of Carbone Dioxide $\left(\mathrm{CO}_{2}\right)$ emission is caused by transport activities which are closely related to logistics activities [5]. Research on lean and green logistics is rare compared to research on lean manufacturing system. Thus, the main purpose of this paper is to conduct a comprehensive review of research analysis on lean and green paradigms in logistics, including their possible collaboration. The research itself contains a statistical analysis of international journal articles closely related to all three topics which are classified by international journal, paradigm, time distribution, research stream and sector-wise focus. Using statistical analysis, it will be possible to generate important findings, some missing areas in the field of lean logistics, green logistics and different ways of thinking on the possible collaboration of the two paradigms.

This study represents a significant contribution for researchers in the academia and for practitioners in the industry. For researchers in the academia mainly 
due to the fact that this research will be the first of its kind that will take into account both paradigms, with their collaboration in the field of logistics. For the industry, it will provide an insight into new trends and possible contributions from each paradigm including their combination. Many researchers mostly focused on one phenomenon rather than considering both of them at the same time. The importance of joint research in this case is significant because the implementation of such a common system would cause more efficiency and have a double effect from cost effectiveness and environmental friendliness. Both paradigms can operate complementarily, but often they do not. Lean solutions are sometimes not sustainable, so it is difficult to find an optimum between lean and green, however, some researchers stated that the adoption practices of lean manufacturing, consequently also lean logistics, will improve the environmental performance of production facilities or in other words, lean is green [6].

Researchers Bergmiller \& McCright [7] further suggest that lean companies, which include green practices, achieve better lean results, in comparison to companies which do not. In short, their findings indicate that only when both paradigms are implemented simultaneously, they can disclose their full potential and make a greater contribution than if they were implemented separately. As such, Karp [8] and Bergmiller \& McCright [7] emphasize that while lean practices can lead to positive environmental contributions, conversely environmental practices often lead to improved lean practices.

The next chapter presents the methodology used for the purposes of this research which enabled an extensive, systematic review of research analysis in the mentioned three fields presented.

\section{METHODOLOGY}

An extensive, systematic review analysis of global research in the world has been conducted in the fields of lean logistics (LL), green logistics (GL) and green and lean logistics (G\&LL) by reviewing 98 scientific papers (majority included in the references) from 35 international journals. The research has been restricted to papers which contained specific keywords related to lean logistics and green logistics in most up-to-date on-line research databases Emerald Online, Science Direct, Springer Link, Elsevier, and Taylor \& Francis portals. The key words were chosen from our past and present academia research and practical experience.

Then, the choices were narrowed to and focused only on international journal papers which contained specific key words closely associated to lean logistics and green logistics. At the same time key words containing supply chain, production or manufacturing were mainly excluded. The main reason lies in the fact that the objective was to narrow the scope of the research to a specific field - logistics rather than supply chain management or production and manufacturing.

The same methodology was applied by Jasti \& Kodali [9] for the review of research analysis of lean production from which the basis of international journals set was also obtained. The key words related to green logistics were: green thinking, sustainable logistics, and reverse logistics. Those related to lean logistics included lean thinking, just-in-time, lean processes, etc. To find the related papers containing both areas, the combination of the above mentioned followed. It was further noted that some of the international journals have very few numbers of published papers, as well as a lack of a narrow focus on any part of lean logistics, green logistics and/or green and lean logistics.

A sample size required special attention to formulate appropriate conclusions, which is why the statistical analysis with the scientific abductive approach was combined [10]. This method is based on researchers' newly obtained knowledge which arises during data analysis and is supported by a theoretical basis.

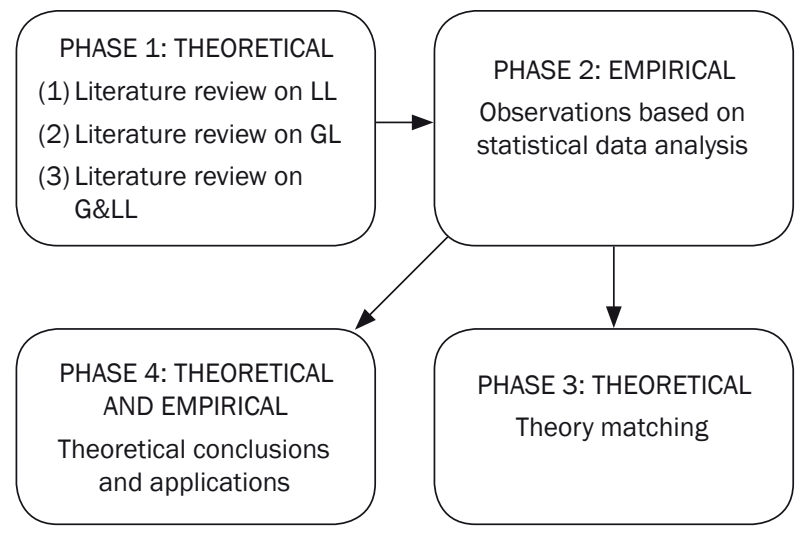

Figure 1 - Abductive reasoning process

The structure of the reasoning process consists of four phases (Figure 1):

1) Theoretical overview where conceptual and descriptive methods were used. Conceptual phase consists of basic concepts of articles, containing individual topics (lean logistics - LL, green logistics - GL and green and lean logistics - G\&LL), whereas the latter descriptive employs an explanation or description of individual topics and performance issues.

2) The empirical phase features an empirical methodology which employs qualitative approaches to collecting primary data for our database and a statistical analysis for each specific area;

3) Theory matching between theory findings and statistical analysis findings; and at the end,

4) Theoretical conclusions and applications. 


\section{LEAN PARADIGM IN THE FIELD OF LOGISTICS}

It is no novelty that the beginning of lean philosophy comes from the Toyota manufacturing system [1113] and that it is also a subject of the work entitled The Machine that Changed the World [14] which highlighted the Japanese production methods in comparison to traditional Western mass production systems. Many of the steps required in the factory to physically create a product add little or no value to customers. Taiichi Ohno was one of the beginners of lean paradigm. He worked in the Toyota Production System in the 1980s and identified seven wastes, activities which are: (1) production of goods not yet ordered, (2) waiting, (3) rectification of mistakes, (4) excess processing, (5) excess movement, (6) excess transport, and (7) excess stock $[15,16]$.

Since there are not only manufacturing and/or production created activities which add no value, industry started to redirect their focus on logistics non-value-added activities. From here on a new paradigm, lean logistics appeared. Womack and Jones [17] studied the transformation of the Toyota US parts distribution system, back to the second-tier parts manufacturer of a replacement bumper and compared it with its system in Japan. Even Toyota saw lean improvements in logistics especially in the fields of manufacturing, delivery, ordering, warehouse management, dealers and network structure. According to Baudin [18], lean logistics is a logistical dimension of lean manufacturing. Its primary objective is to deliver the right materials to the right locations, in the right quantities, and in the right presentation; its second objective is to do all these activities most efficiently. The same author continues that lean logistics could be and has been the paradigm applied to services, but they have focused on the manufacturing as a domain whereas it is rich in logistics concepts, approaches and techniques which can be addressed as lean because either they are part of the Toyota Production System or they were adopted from it for application in different contexts.

According to Jones, Hines \& Rich [19] lean logistics also takes its fundamental philosophy from the Toyota Production System and is based around the extended one right along the supply chains from customers right back to raw material extraction. Bowersox, Closs \& Cooper [20] state that lean logistics refers to the superior ability to design and administer systems to control movement and positioning of raw materials, work-inprocess, and finished inventories at the lowest cost. In other words, lean logistics can simply be described as a way of recognizing and eliminating wasteful activities from the supply chain in order to increase product flow and speed.

Many companies have implemented lean practices and thereby improved the efficiency of their own processes. Leaner processes create value by eliminating wastes in supply chains [21] including the production of goods that have not yet been ordered, waiting time, repairing of errors and excess processing, movements, transport and stock [19].

Since lean logistics systems brought logistics to a new level of efficiency, the latter enables faster delivery of goods to customers which in contrast surely affects our environment. It is therefore an inevitable global trend to develop and adopt green logistics management in every sphere of national industry, especially in the production and transport sectors [22-24].

\section{GREEN PARADIGM IN THE FIELD OF LOGISTICS}

Murphy, Poist \& Braunschweig [25] state that although the roots of environmentalism go back to the 1960s, the first real surge in environmental policies did not occur until the 1970s. Environmentalism appears to have come of age during the 1980s, a decade where companies started to establish environmental policies. During 1990s, environmentalism as the practice of responding to environmental issues in a socially responsible manner has become increasingly important. It has been characterized as one of the most significant forces shaping the economy [25]. Murphy et al. [25] in their research found out that $60 \%$ out of a group of 133 managers surveyed considered environmental issues to be highly important and $82 \%$ expected that the importance would further increase in the years to come. Moreover, some corporate executives have indicated that the 1990s will be the decade of the environment [26].

Many articles based on the concern for the environment have at that time also been written in the field of business and logistics [25, 27-30]. Porter \& van der Linde [31] have also discussed the fundamentals of greening as a competitive initiative. Their basic reasoning was that investments in greening can be resource-saving, waste-eliminating and productivity improving. They state that green initiatives could lower not only the environmental impact of a business but also raise efficiency, possibly creating significant competitive advantages in innovation and operations. Skjoett-Larsen [32] wrote a foresight work on European companies facing new challenges in the next millennium one of which is also green logistics. The author stipulates that within the next five to ten years green supply chains will increasingly dominate the theory and practice in the logistics area. Similarly was also indicated by Murphy \& Poist [33] who compared US and non-US (Canadian and West European) firms with respect to the selected propositions regarding environmental issues, practices and strategies. They've indicated that both firms tend to share similar perspectives and practices regarding the management 
of environmental logistics and that green concerns will broaden the scope of logistics as well as influence the way that logisticians do their jobs. Moreover, with green logistics which involves the integration of environmental aspects in logistics [34], a completely new sub-sector of logistics appeared, using new models and tools as green logistics management. The trend is therefore to switch from traditional logistics to green logistics [2].

Later on the popular areas for environmental research involved mostly purchasing related areas as in $[35,36]$ and others. At that time there was also an increased interest in reverse logistics [37, 38, 39].

Nowadays, modern businesses are facing an increasingly complex legislation with respect to environmental issues. The trust of many of these laws is to place the so called cradle-to-grave responsibilities on companies for products and processes. The logistics discipline is well-qualified to deal with these cradleto-grave issues because of logistics' focus on supply chain management, which emphasizes the control of materials from suppliers, through value-added processes right to the customer [40]. Environmentalism appears to have arrived as a key issue faced by the logistics managers. Leading logistics textbooks now include the green movement [41] and recycling [42] as emerging environmental logistics issues. As concern for the environment is nowadays of significant importance, we also have to take into account lean logistics. Modern lean logistics therefore, uses sophisticated transport and manipulation equipment, modern technologies on logistics terminals and warehouses to secure lean supply chains. Combining all those elements and developing environmentally-friendly logistics is an issue which has been very topical in recent years.

\section{INTEGRATION OF THE TWO PARADIGMS}

There are separate streams of research on lean logistics and green logistics; however, few researchers have explored some cross-sections of these two paradigms [43, 44, 45, 46]. This represents a critical point for companies which are most likely missing opportunities for synergies that are available with improved simultaneous introduction and also may fail in addressing important trade-offs that may occur when there are incompatibilities between strategic initiatives [47]. For example, green and lean strategies can be seen as compatible initiatives because of their common focus on waste removal $[48,49,50]$.

The green paradigm is operationalized through green initiatives [51], which are supported by methods and tools that include environmental operations management or green operations $[52,53]$, green manufacturing [48], green supply chains [54], reverse logistics [55], green building [56], sustainable value stream mapping [57] and life cycle assessment [58]. As lean paradigm also strives to eliminate waste in every area of design, production, factory management and supplier network [59], its alignment with the green paradigm, and its methods and tools, seems natural.

Kleindorfer et al. [48] assert that due to the wider adoption of lean practices in supply chain and the growing pressure on environmental management, companies started to incorporate these environmentally-friendly practices in their own scheme of reducing waste. The implementation of both initiatives, lean and green, despite its simplicity has intended to illustrate the potential synergies and conflicts that arise when any combination of green or lean is implemented. The combination of both paradigms adds management complexity of logistics of a certain company. Neither should the obstacles be overlooked when one wants to achieve the rearranging of logistics according to principles of green and lean, including the lack of ecological awareness [60], a general default principle that ecology does not pay off [61], and the perception that green initiatives are time consuming and expensive.

Rothenberg, Pil \& Maxwell [62] are of the opinion that only a handful of environmental experts examined the relationships between the various aspects of lean and green practices. Porter \& Van der Linde [31] argue that there is an issue about two completely different things, but some experts have recognized their possible cooperation. Dües, Tan \& Lim [63] described green as a public good blending of lean and interprets these positive side-effects as efforts to reduce waste and reduce pollution. Many companies have a natural tendency to move towards green practices. Generally speaking, most of research concerning the link between lean and green touch the efficient use of energy and resources and reduce waste and pollution $[64,65]$. Certain companies therefore resist the implementation of environmental initiatives because they can be time-consuming and expensive [31]. Lean production and mass adaptation need more settings that generate more waste and consume more energy [63]. Changing production technologies which would produce more environmentally responsible processes and products require a lot of pre-investment for which the return is not necessarily yield realized in the short term, as with the lean cost-declining strategies [60]. Improvements in production systems can lead to direct and indirect benefits for environmental management, often in the form of reduction of waste [66]. The objectives set to achieve leanness thus become a catalyst for the successful implementation of green practices and also help to achieve the desired objectives $[63,67,62]$. Those who studied the intersection of lean and green paradigms in supply chain found a cross-section in the following parameters: management techniques and reducing waste, people and organization, reducing delivery time, key performance indicator (the level of service), and also a set of common 
tools and practices that they share. The main common point lies in the objective of waste disposal of both paradigms. Nevertheless, a waste of both paradigms is defined otherwise but both target the removal of excess: the waste in the broadest sense. Lean logistics focuses on removing eight wastes related to efficient flow, while green logistics focuses on green wastes in the form of inefficient use or waste production [48, 68, $6]$. Despite the fact that these two paradigms have different goals for the removal of waste, they respectively target the same type of waste, in particular, storage, transport and production or outputs, which are not products [62].

Excessive stock in a company means additional risks and retention of capital for the company. Moreover, stocks need storage space which must be adequately lighted, heated or cooled, which is considered as waste from the environmental perspective [69]. As for transport, both paradigms respectively target less transport to reduce costs $[70,6]$.

Simpson \& Mason [67] developed a sustainable value stream mapping by adding sustainable metrics. Similarly, Karp [8] and Faulkner and Badurdeen [71] advise adding environmental aspects to value stream mapping. Other additions to the conventional value stream mapping includes mapping flows connected with energy use, water and material use in accordance with finding the hidden sources of wastes in the value stream [68]. Further, by studying the winners and finalists of the Shingo awards, Simpson \& Mason [67] identified the link between green operations and lean results. They found out that lean companies, which include green practices, achieve better lean results than companies that do not.

Based on the results from this chapter it was found that green practices can help businesses become leaner. In short, these findings indicate that only when both paradigms are implemented simultaneously, can they disclose their full potential and make a greater contribution than if they were implemented separately. As such, Karp [8] and Bergmiller \& McCright [7] emphasize that while lean practices can lead to environmental contributions, conversely environmental practices often lead to improved lean practices.

\section{ANALYSIS AND RESULTS}

In the following sub-sections our results will be presented and discussed.

\subsection{List of selected international journals and the number of articles per each journal}

This empirical study was conducted by employing qualitative approaches to collect primary data for our database and by statistical analysis for each specific area. There were 35 international journals reviewed and 98 scientific articles examined. The selected international journals were the following: International Journal of Production Economics (IJPE), Journal of Manufacturing Technology Management (JMTM), International Journal of Physical Distribution and Logistics Management (IJPDLM), The International Journal of Logistics Management (IJLM), Logistics Information Management (LIM), International Journal of Lean Six Sigma (IJLSS) and other.

Articles were divided into three topics: lean logistics (LL), green logistics (GL) and green and lean logistics (G\&LL).

There were $57.14 \%$ of reviewed articles published on the topic green logistics, $29.59 \%$ on lean logistics and $13.27 \%$ on green and lean logistics (Table 1).

Table 1 - Share of selected international journals per topic

\begin{tabular}{|c|c|c||}
\hline \hline Topic & Number of articles & $\%$ \\
\hline \hline G\&LL & 13 & 13.27 \\
\hline GL & 56 & 57.14 \\
\hline LL & 29 & 29.59 \\
\hline SUM & 98 & 100 \\
\hline
\end{tabular}

Figure 2 presents the analysis of articles per individual topic (lean logistics - LL, green logistics - GL and green and lean logistics - G\&LL) based on the years in which they were published. The timeline of the examined articles considers the years between 1994 and 2015.

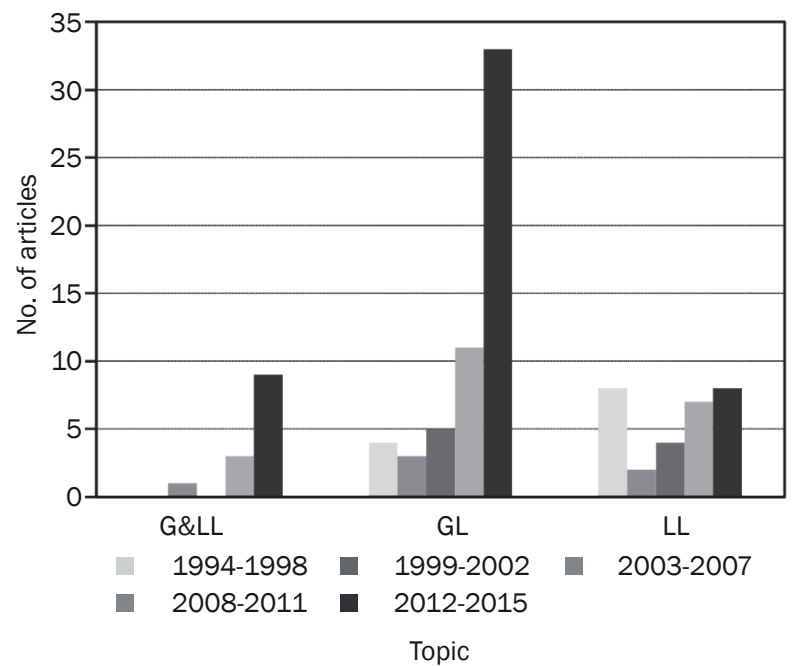

Figure 2 - Year-wise frequency distribution of articles per lean logistics, green logistics and green and lean logistics topic

One can see the growth in all three topics since the year 2011. The most published articles were according to our research were on the topic of green logistics, where the maximum number of published articles was 13 in the year 2013; also most of them were published in IJPDLM (13; 9 in the last 4 years) and IJPE (8; 7 in the last 5 years). The maximum number for the topic of lean logistics were five revised articles in the year 
1997 and also five in 2011. Most of the revised articles were published in IJPDLM (7) followed by JMTM (3) and also LIM (3). For the articles containing the topic of lean and green together, the following results were obtained: the year 2015 has the highest number (5) of published articles based on this topic and subsequently the year 2014 has the second highest score. It was found that the international journals, published on this topic, were IJLM (2), IJLSS (2), IJPDLM (2) and IJPE (2). One has to take into account as well that there were more articles concerning all three topics published on the global scale, but our results are only based on our research on the selected 98 articles.

Figures 3, 4 and 5 present the distribution in different research streams with respect to research methodologies. Out of a total of 29 considered lean logistics articles there were $55.17 \%$ (16) of the research type and $37.93 \%$ (11) of the case study type. Out of a total of 56 green logistics articles there were $73.21 \%$ (41) of the research type and $14.29 \%$ (8) of the case study type. For the considered green and lean logistics articles (13) there were also $67 \%$ (8) of the research type and $33 \%$ (4) of the conceptual nature. For all three one may notice a certain domination in the research typology of articles.

Out of 11 case study lean logistics articles, 6 (54.54\%) were written from 1994 to 2005 and out of 16 articles, 11 (68.75\%) research articles were written from 2006 to 2015. Out of 41 green logistics articles, only $5(12.19 \%)$ research articles were written until 2006 and out of 8 case study articles, 7 (87.50\%) research articles were written between 2006 and 2015. Out of 8 green and lean logistics research articles, only $1(12.5 \%)$ research article was written until 2005. All four green and lean logistics conceptual articles were written from 2006 to 2015.

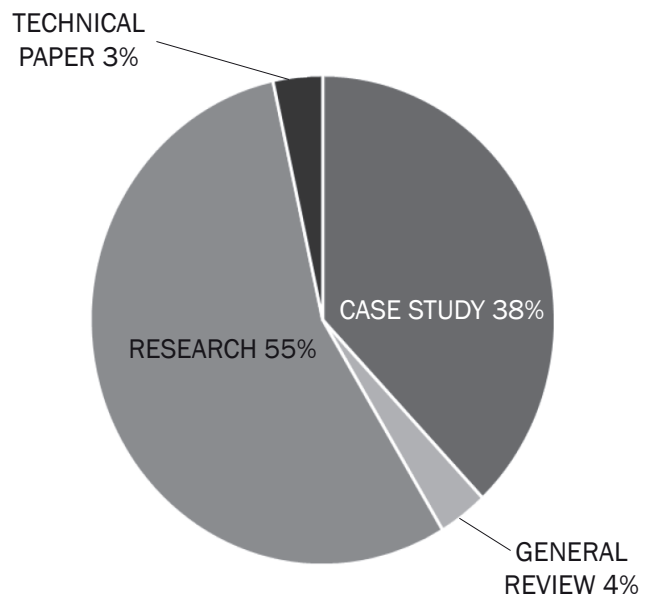

Figure 3 - Distribution of different article types on lean logistics topic

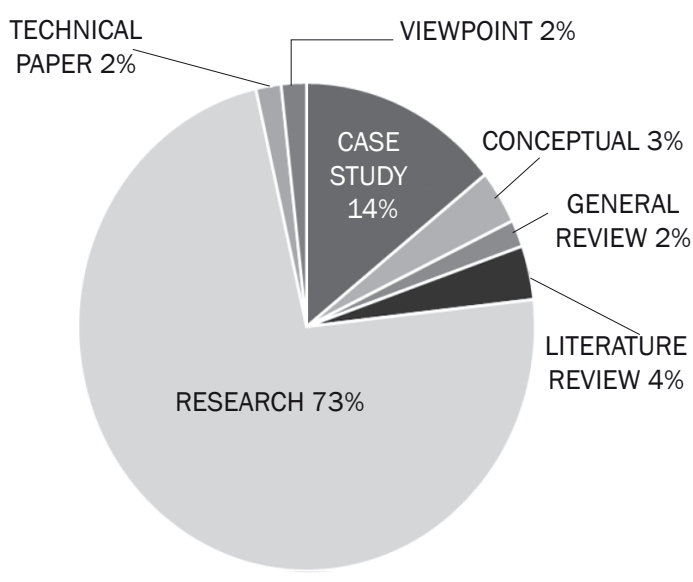

Figure 4 - Distribution of different article types on green logistics topic

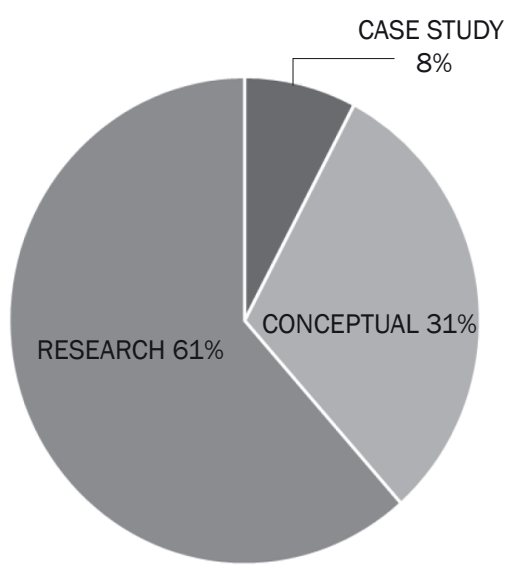

Figure 5 - Distribution of different article types on green and lean logistics topic

\subsection{Frequency distribution of type of sectors covered by researchers}

This analysis examines the determination of the frequency distribution of type of sectors covered by researchers. For lean logistics topic (see Figure 4) most of the articles (20.69\%) come from the manufacturing industries. Most of the revised articles were published from 2006 to 2015 . There were $19.23 \%$ that indicated no specific sector and $13.79 \%$ of revised articles were based on automotive sector. The latter articles were written between 1994 and 2005. For the green logistics topic in most of the revised articles (33.93\%) no specific sector was identified and for $28.57 \%$ of all articles the logistics sector and logistics sector in combination with others, e.g. ICT, food processing, service, transport and manufacturing was identified. For the green and lean logistics topics no specific sector for $46.15 \%$ of all the revised articles was indicated and 
$15.38 \%$ for automotive sector (50\% from 1994-2005 and 50\% from 2006-2015).

\section{DISCUSSION}

To the best of our knowledge the present research is the first review of research analysis on lean logistics, green logistics and green and lean logistics published between the years of 1994 and 2015. The sample of 98 scientific articles found in 35 international journals is closely connected to logistics sector. There also exists a relatively small number of articles on the researched topics. From this on the latter constitutes a relevant sample and a good view of the current state of research on these topics.

Based on the findings on the volume of papers on individual topics (green logistics: $57.14 \%$, lean logistics: $29.59 \%$ and green and lean logistics; 13.27\%), a growth has been indicated in all three topics since 2011. The latter was also indicated by Google Trends which indicated constant growth per individual topic,

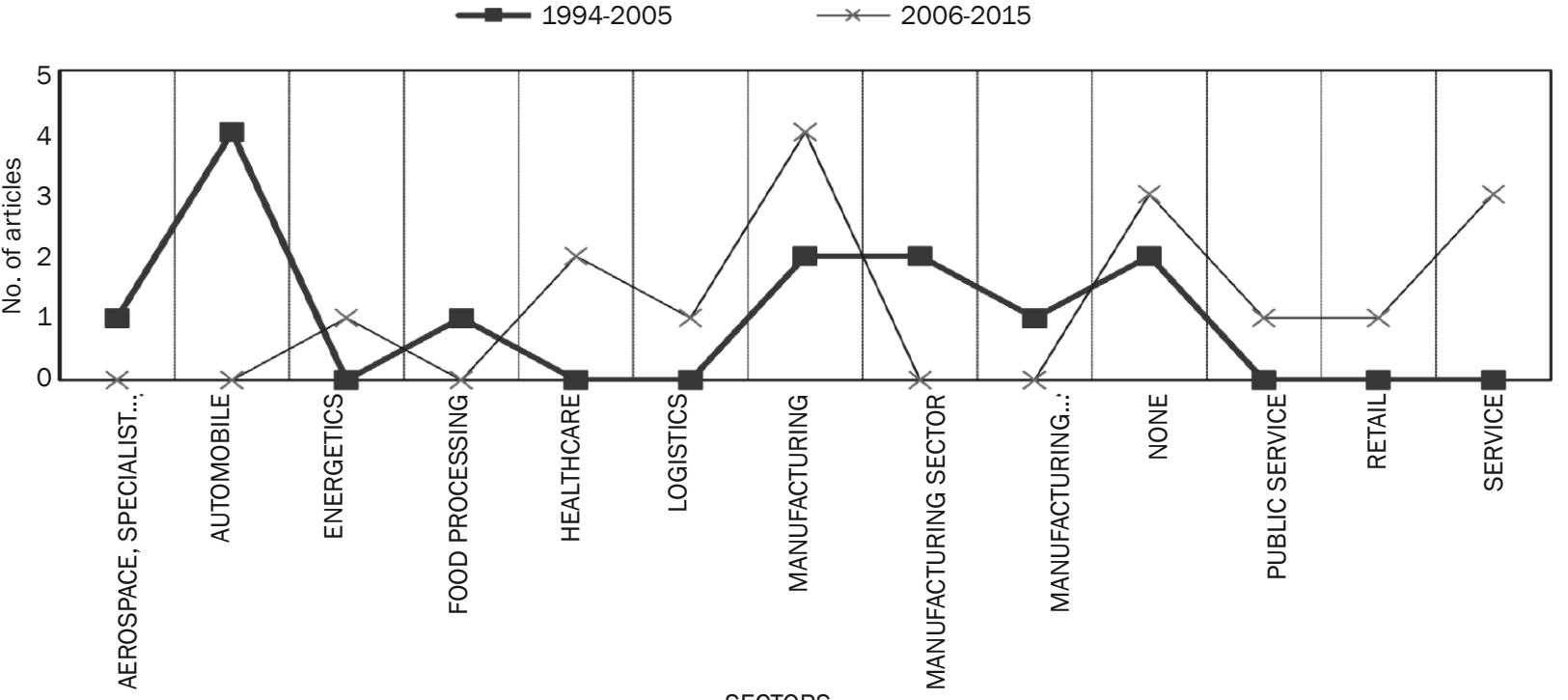

SECTORS

Figure 6 - Frequency distribution of type of sectors covered by researchers for lean logistics topic

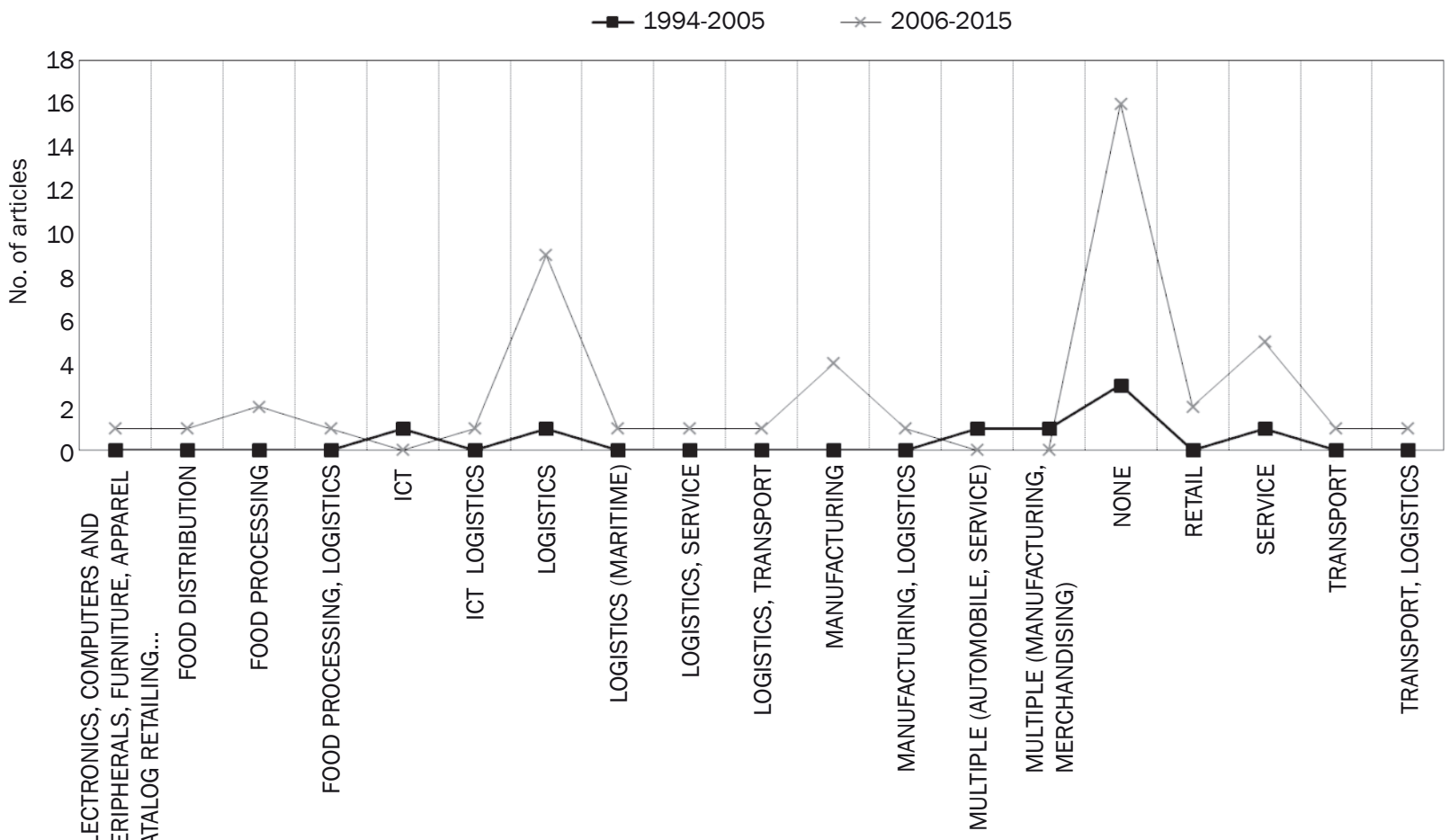

SECTORS

Figure 7 - Frequency distribution of type of sectors covered by researchers for green logistics topic 


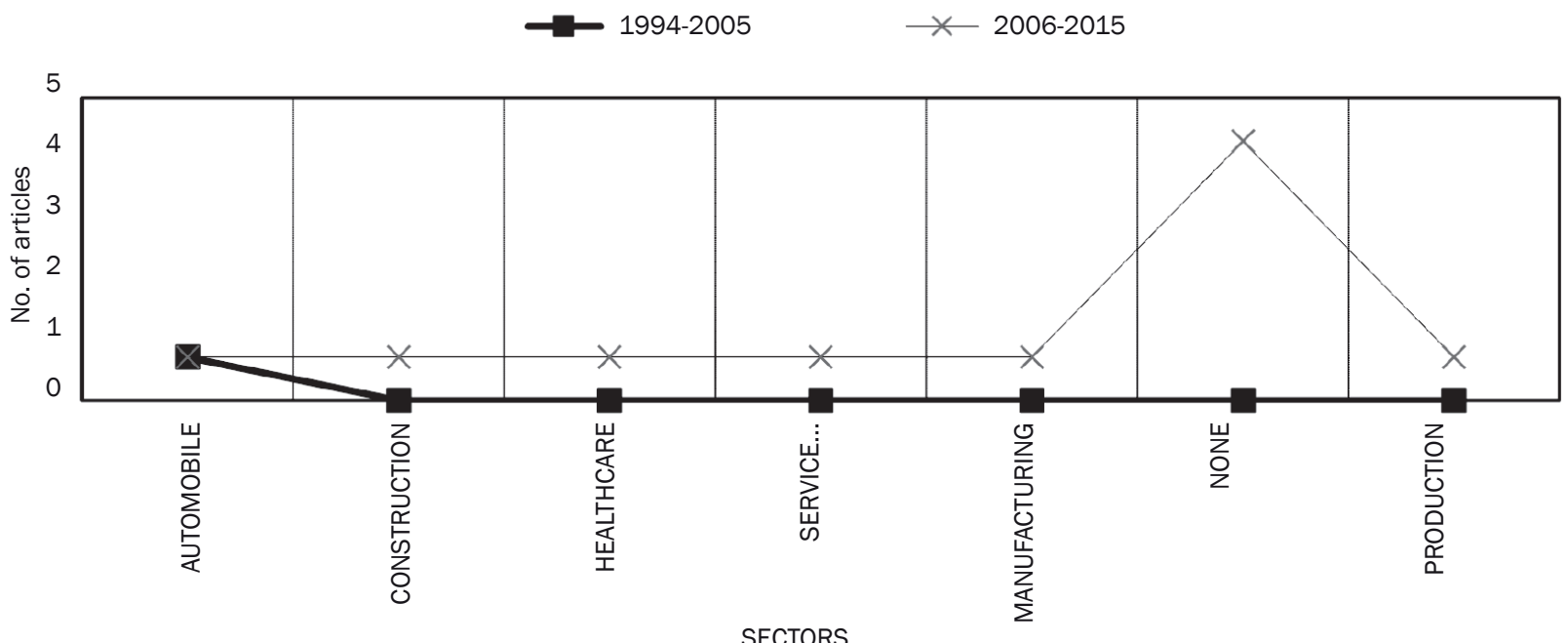

Figure 8 - Frequency distribution of type of sectors covered by researchers for green and lean logistics topics

whereas the largest interest goes to green logistics (max. 13 in 2013). It is assumed that the reason lies in the current tendency to tackle the issue of climate change, tendency towards sustainable solutions on a global scale and also the necessity of greening of logistics. All this coupled with financial initiatives for green solutions (e.g. through EU projects) provide interest in green solutions for logistics. Less research on lean logistics is also logical because researchers associate leanness almost exclusively with production/ manufacturing and not directly with logistics. Also, new trends emerge in logistics, for example agile logistics and le-agile logistics, which comprise leanness and agility solutions in logistics. An increase in the number of green and lean logistics articles was noticed. Some of them have a conceptual nature $(30.77 \%)$ and most of them are of the research type (61.54\%). It was observed that this is a new opportunity for researchers to fill a research gap and to combine the two paradigms for a greater affect. From the aspect of industry it would only be reasonable to combine the two paradigms to develop a more powerful, waste-free logistics system.

It is evident that for the lean logistics topic the maximum number of articles (20.69\%) comes from the manufacturing industries, since manufacturing is rich in logistics concepts and the paradigm itself started to develop there. Most of the revised articles were published from 2006-2015, which we ascribe to the fact that manufacturers have just recently started to apply lean concepts also to logistics processes in manufacturing departments. There was no specific sector indicated in $19.23 \%$ of the revised articles. There were $13.79 \%$ of revised articles based on automotive sector which is also one of the sectors which demand efficient, waste-free logistics processes. For the green logistics paradigm in most of the revised articles, no specific sector could be identified, and $28.57 \%$ of all articles were identified as logistics sector and logistics sector in combination with others, e.g. information communication technology, food processing, service, transport and manufacturing. Since the green concept nowadays has been implemented almost in all sectors, the logistics concept will not be an exception since it is one of the most significant $\mathrm{CO}_{2}$ emissions contributors. For $50 \%$ of green and lean logistics revised articles no specific sector was indicated and almost $14 \%$ of them belong to automotive sector. This is due to the fact that most of the articles were largely conceptual in nature and as mentioned previously it is only logical that the automotive sector is the second since it invests largely in integrated systems.

\section{CONCLUSION}

Logistics plays a vital role in economic systems and in everyday life. Reducing logistics costs became an increasingly important task for managers working in various logistics areas. From warehousing, identification systems, packing and order picking all the way to load and transport safety. However, besides economy empowering, which is the most important side-effect of an efficient and cost-effective, lean logistics, one has to take into account the topical weather changes and global sustainability. Here, many important studies on green logistics are being carried out. This paper therefore represents a review of research analysis on lean logistics, green logistics and green and lean logistics. The research itself contains a sample of 98 international journal articles closely related to all three topics and encompassing areas such as supply chain management, manufacturing and production.

This review of studies represents a breakthrough in the fields of lean logistics, green logistics and green 
and lean logistics, mainly due to the fact that the sample size of the articles (98) as well as the number of international journals (35) is larger than the ever considered sample size on the mentioned topics. Secondly, our statistical analysis formed interesting research findings; for example, over the last few years there was an increased interest in research on all three topics, yet, there is a gap when it comes to the research of green and lean logistics. Moreover, the findings indicate the domination in research typology for all three topics. There are some gaps in the fields of lean logistics and green logistics identified, and also different ways of thinking about the possible interaction of the two paradigms. It is evident that for each paradigm some research has been done; however, there has been great interest from the industry on the green and lean logistics topic. In this respect we agree with Kleindorfer et al. [48] who investigated the combination of lean, green and global strategy of supply chain, and concluded that once the environmental regulations become increasingly stringent, companies will be forced to deal with this kind of interaction of paradigms. The synergy of each partner affects the other in a positive manner and thereby increases the benefits of this type of symbiosis.

To sum up, this review of research presents a starting point for future research in which a conceptual framework will be developed. A framework will look for cross data between different information gathered by the approach of the lean and green paradigms. A key indicator of the first aspect will be costs due to the trend of elimination of wastes, while the key indicator of the second will be lowering of $\mathrm{CO}_{2}$ emissions at all levels. Based on the two basic objectives (minimal costs and $\mathrm{CO}_{2}$ emission reduction) we want to propose a hybrid model of lean and green intralogistics. A model will cover both economical benefit and sustainable contribution and will also encompass at least three intralogistics areas, e.g. design planning ergonomics in the workplace and internal transport processes. The model will enable the evaluation of a green and lean intralogistics of an individual company. It could be used as a tool for potential improvements and it could also be applied to other logistics areas.

VASKA PEJIĆ, mag. inž. log. ${ }^{1}$

E-mail: vaska.pejic@um.si

Red. Prof. Dr. TONE LERHER ${ }^{1}$

E-mail: tone.lerher@um.si

Izred. Prof. Dr. BORUT JEREB ${ }^{1}$

E-mail: borut.jereb@um.si

Izred. Prof. Dr. ANDREJ LISEC ${ }^{1}$

E-mail: andrej.lisec@um.si

${ }^{1}$ Univerza v Mariboru, Fakulteta za logistiko

Mariborska cesta 7, 3000 Celje, Slovenija

\section{VITKA IN ZELENA PARADIGMA V LOGISTIKI: PREGLED OBJAVLJENIH RAZISKAV}

\section{POVZETEK}

Članek predstavlja sistematični pregled raziskav na temo vitke logistike, zelene logistike ter kombinacijo obeh paradigem znotraj logistike. Čeprav že obstajajo predhodne raziskave na vse tri teme, se le nekatere osredotočajo na področje logistike. Sedanja analiza obsega pregled 98 znanstvenih člankov iz 35 mednarodnih revij, objavljenih med leti 1994 in 2015. Raziskave so razvrščene glede na: revijo, paradigmo, čas objave, raziskovalni tok ter sektor. Kljub temu, da ena izmed ključnih ugotovitev kaže na to, da se je $\checkmark$ zadnjih nekaj letih raziskavanje vseh treh tem povečalo, obstaja raziskovalna vrzel glede presečnega raziskovanja obeh paradigem. Za vse tri teme smo identificirali prevlado $\checkmark$ raziskovalni tipologiji, večina člankov na temo vitke logistike prihaja iz proizvodnega sektorja medtem, ko za večino člankov na temo zelene logistike in kombinacijo obeh paradigem, nismo identificirali nobenega sektorja.

\section{KLUUČNE BESEDE}

logistika; vitko; zeleno; pregled raziskav;

\section{REFERENCES}

[1] Christopher M. Logistics \& Supply Chain Management. Pearson Education Limited; 1992.

[2] Beškovnik B, Twrdy E. Green logistics strategy for South East Europe: to improve intermodality and establish green transport corridors. Transport. 2015;27(1): 25-33.

[3] Armstrong \& Associates I. Global and Regional Infrastructure, Logistics Costs, and Third-Party Logistics Market Trends and Analysis. Armstrong \& Associates, Inc.; 2014.

[4] 2008 Supply Chain Monitor "How Mature is the Green Supply Chain?". BearingPoint, Inc.; 2008.

[5] Kranke A. Effizienz statt Leistung: Logistik Inside; 2008.

[6] King AA, Lenox MJ. Lean and green? An empirical examination of the relationship between lean production and environmental performance. Production and Operations Management. 2001;10(3):244-256.

[7] Bergmiller GG, McCright PR. Lean Manufacturers' Transcendence to Green Manufacturing. Proceedings of the 2009 Industrial Engineering Research Conference; 2009 May 30 - June 3; Miami, Florida.

[8] Karp HR. Green Suppliers Network: Strengthening and Greening the Manufacturing Supply Base. Environmental Quality Management. 2005;15(2):37-46.

[9] Jasti NVK, Kodali R. Lean production: literature review and trends. International Journal of Production Research. 2015;53(3):867-85.

[10] Kovács G, Spens KM. Abductive reasoning in logistics research. International Journal of Physical Distribution and Logistics Management. 2005;35(2):132-44.

[11] Monden Y. The Toyota Production System. Productivity Press; 1983.

[12] Shingo S. Non-Stock Production: The Shingo System for Continuous Improvement. Productivity Press; 1988. 
[13] Ohno T. The Toyota Production System: Beyond LargeScale Production. Productivity Press; 1988.

[14] Womack JP, Jones DT, Roos D. The Machine That Changed the World. Rawson Associates; 1990.

[15] Japan Management Association. Kanban Just-in-time at Toyota. Productivity Press; 1985.

[16] Monden Y. Toyota Production System: An Integrated Approach to Just-In-Time. 2nd ed. Industrial Engineering and Management Press; 1993.

[17] Womack J, Jones DT. Lean Thinking: Banish Waste and Create Wealth for Your Corporation. Simon and Schuster; 1996.

[18] Baudin M. Lean Logistics: The Nuts and Bolts of Delivering Materials and Goods. Productivity Press; 2004.

[19] Jones DT, Hines P, Rich N. Lean logistics. International Journal of Physical Distribution \& Logistics Management. 1997;27(3-4):153-73.

[20] Bowersox D, Closs DJ, Cooper MB. Supply Chain Logistics Management. McGraw-Hill; 2002.

[21] Günthner WA, Tenerowicz P. Paths toward greater energy-efficient intra logistics; 2010.

[22] Dunning JH, Fortanier F. Multinational enterprises and the new development paradigm: consequences for host country development. Multinational Business Review. 2007;15(1):25-46.

[23] Carter CR, Rogers DS. A framework of sustainable supply chain management: moving toward new theory. International Journal of Physical Distribution and Logistics Management. 2008;38(5):360-87.

[24] Kovács G. Corporate environmental responsibility in the supply chain. Journal of Cleaner Production. 2008;16(15):1571-8.

[25] Murphy PR, Poist RF, Braunschweig CD. Role and relevance of logistics to corporate environmentalism. International Journal of Physical Distribution and Logistics. 1995;25(2):5-19.

[26] Limoubpratum C, Shee H, Ahsan K. Sustainable distribution through coopetition strategy. International Journal of Logistics Research and Applications. 2014;18(5):1-18.

[27] Murphy PR, Poist RF, Braunschweig CD. Management of environmental issues in logistics: current status and future potential. Transportation Journal. 1994;34(1):48-56.

[28] Wu H, Dunn SC. Environmentally responsible logistics systems. International Journal of Physical Distribution \& Logistics Management. 1995;25(2):20-38.

[29] Mclntyre K, Henham A, Pretlove J. Logistics Performance Measurement and Greening Supply Chains: Diverging Mindset. The International Journal of Logistics Management. 1998;9(1):57-68.

[30] Van Hoek RI. From reversed logistics to green supply chains. Supply Chain Management: An International Journal. 1999;4(3):129-34

[31] Porter ME, Van der Linde C. Green and competitive: ending the stalemate. Harvard Business Review. 1995;73(5):120-34.

[32] Skjoett-Larsen T. European logistics beyond 2000. International Journal of Physical Distribution \& Logistics Management. 2000;30(5):377-87.

[33] Murphy PR, Poist RF. Green Perspectives and Practices: a "comparative logistics" study. Supply Chain Management: An International Journal. 2003;8(2):122-31.
[34] Dekker R, Bloemhof J, Mallidis I. Operations Research for green logistics - An overview of aspects, issues, contributions and challenges. European Journal of Operational Research. 2012;3(16):671-9.

[35] Carter C, Ellram L, Ready J. Environmental purchasing: benchmarking our German counterparts. International Journal of Purchasing and Materials Management. 1998;34(4):28-38.

[36] Carter C, Dresner M. Purchasing's role in environmental management: cross-functional development of grounded theory. Journal of Supply Chain Management. 2001;37(3):12-26.

[37] Stock JR. Development and Implementation of Reverse Logistics Programs. Oak Brook, IL: Council of Logistics Management; 1998.

[38] Carter C, Ellram L. Reverse Logistics: a review of the literature and framework for future investigation. Journal of Business Logistics. 1998;19(1):85-103.

[39] Goldsby T, Closs D. Using activity-based vosting to reengineer the reverse logistics channel. International Journal of Physical Distribution \& Logistics Management. 2000;30(6):500-14.

[40] Marchet G, Melacini M, Perotti S. Environmental sustainability in logistics and freight transportation. Journal of Manufacturing Technology Management 2014;25(6):775-881.

[41] Kumar V, Holt D, Ghobadian A, Garza-Reyes JA. Developing green supply chain management taxonomy-based decision support system International Journal of Production Research. 2014;53(21):1-18.

[42] Tacken J, Sanchez Rodrigues VS, Mason R. Examining $\mathrm{CO}_{2}$ reduction within the German logistics sector. The International Journal of Logistics Management. 2014;25(1):54-84.

[43] Dhingra R, Kress R, Upreti G. Does lean mean green? Journal of Cleaner Production. 2014;85(2014):1-7.

[44] Pampanelli AB, Found P, Bernardes AM. A Lean and Green Model for a production cell. Journal of Cleaner Production. 2014;85:19-30.

[45] Wong WP, Wong KY. Synergizing an ecosphere of lean for sustainable operations. Journal of Cleaner Production. 2014;85:51-66.

[46] Garza-Reyes JA. Green lean and the need for Six Sigma. International Journal of Lean Six Sigma. 2015;6(3):226-48.

[47] Johansson G, Sundin E. Lean and green product development: two sides of the same coin? Journal of Cleaner Production. 2014;85:104-21.

[48] Kleindorfer PR, Singhal K, Van Wassenhove LN. Sustainable Operations Management. Production and Operations Management. 2005;14(4):482-92.

[49] Verrier B, Rose B, Caillaud E, Remita H. Combining organizational performance with sustainable development issues: the Lean and Green project benchmarking repository. Journal of Cleaner Production. 2014;85:83-93.

[50] Garza-Reyes JA. Lean and green - a systematic review of the state of art literature. Journal of Cleaner Production. 2015;102:18-29.

[51] Digalwar AK, Tagalpallewar AR, Sunnapwar VK. Green manufacturing performance measures: an empirical investigation from Indian manufacturing industries. Measuring Business Excellence. 2013;17(4):59-75. 
[52] Gupta M, Sharma K. Environmental operations management: an opportunit for improvement. Production Inventory Management Journal. 1996;37(3):40-6.

[53] Nunes B, Bennett D. Green operations initiatives in the automotive industry: an environmental reports analysis and benchmarking study. Benchmarking International Journal. 2010;17(3):396-420.

[54] Zhu Q, Sarkis J, Lai K. Confirmation of a measurement model for green supply chain management practices implementation. International Journal of Production Economics. 2008;111(2):261-73.

[55] Sarkis J. A strategic decision making framework for green supply chain management. Journal of Cleaner Production; 2003;11(4):397-409.

[56] Paumgartten PV. The business case for high-performance green buildings: sustainability and its financial impact. Journal of Facilities Management. 2003;2(1):26-34.

[57] Kurdve M, Hanarp P, Chen X, Qju X, Yan Z, John S, Laring J. Use of environmental value stream mapping and environmental loss analysis in lean manufacturing work in Volvo. Proceedings of the 4th Swedish Production Symposium (SPSS11); 2011 May 3-5; Lund, Sweden.

[58] Kainuma Y, Tawara N. A multiple attribute utility theory approach to lean and green supply chain management. International Journal of Production Economics. 2006;101(1):99-108.

[59] Chauhan G, Singh TP. Measuring parameters of lean manufacturing realization. Measuring Business Excellence. 2012;16(3):57-71.

[60] Mollenkopf D, Stolze H, Tate WL, Ueltschy M. Green, Iean and global supply chains. International Journal of Physical Distribution \& Logistics Management. 2010;40(1-2):14-41.

[61] Disney SM, Naim MM, Towill DR. Dynamic simulation modelling for lean logistics. International Journal of Physical Distribution \& Logistics Management. 1997;27(3-4):174-96.
[62] Rothenberg S, Pil F, Maxwell J. Lean, green, and the quest for environmental performance. Procuction and Operations Management. 2001;10(3):228-43.

[63] Dües CM, Tan KH, Lim M. Green as the new Lean: how to use Lean practices as a catalyst to greening your supply chain. Journal of Cleaner Production. 2013;40:93-100.

[64] Larson T, Greenwood R. Perfect complements: synergies between lean production and eco-sustainability initiatives. Environmental Quality Management. 2004;13(4):27-36.

[65] Yang MG, Hong P, Modi SB. Impact of lean manufacturing and environmental management on business performance: An empirical study of manufacturing firms. International Journal of Production Economics. 2011;129(2):251-61.

[66] Simpson DF, Power DJ. Use the supply relationship to develop lean and green suppliers. 2005(10):60-80.

[67] Simpson D, Mason R. Environmental and Transport Supply Chain Evaluation with Sustainable Value Stream Mapping. 7th Logistics Research Network Conference; 2002 Sep 5-6; Birmingham, UK.

[68] EPA. The Lean and Environment Toolkit, Version 1.0.: The U. S. Environmental Protection Agency; 2007. Available from: http://outsourced-http:// www.epa.gov/lean/

[69] Franchetti M, Bedal K, Ulloa J, Grodek S. Lean and Green: Industrial engineering methods are natural stepping stones to green engineering. Industrial Engineer: IE. 2009;41(9):24-9.

[70] Venkat K, Wakeland W. Is Lean Necessarily Green? Proceedings of the 50th Annual Meeting of the International Society for the Systems Sciences; 2006 July 9-14; Sonoma California.

[71] Faulkner W, Badurdeen F. Sustainable Value Stream Mapping (SUS-VSM): methodology to visualize and assess manufacturing sustainability performance. Journal of cleaner production. 2014;85:8-18. 